\title{
Front Matter: Volume 10201
}

, "Front Matter: Volume 10201," Proc. SPIE 10201, Algorithms for Synthetic Aperture Radar Imagery XXIV, 1020101 (18 May 2017); doi:

$10.1117 / 12.2270670$

SPIE. Event: SPIE Defense + Security, 2017, Anaheim, CA, United States 


\title{
PROCEEDINGS OF SPIE
}

\section{Algorithms for Synthetic Aperture Radar Imagery XXIV}

\author{
Edmund Zelnio \\ Frederick D. Garber
}

Editors

13 April 2017

Anaheim, California, United States

Sponsored and Published by

SPIE 
The papers in this volume were part of the technical conference cited on the cover and title page. Papers were selected and subject to review by the editors and conference program committee. Some conference presentations may not be available for publication. Additional papers and presentation recordings may be available online in the SPIE Digital Library at SPIEDigitallibrary.org.

The papers reflect the work and thoughts of the authors and are published herein as submitted. The publisher is not responsible for the validity of the information or for any outcomes resulting from reliance thereon.

Please use the following format to cite material from these proceedings:

Author(s), "Title of Paper," in Algorithms for Synthetic Aperture Radar Imagery XXIV, edited by Edmund Zelnio, Frederick D. Garber, Proceedings of SPIE Vol. 10201 (SPIE, Bellingham, WA, 2017) Seven-digit Article CID Number.

ISSN: 0277-786X

ISSN: 1996-756X (electronic)

ISBN: 9781510609037

ISBN: 9781510609044 (electronic)

Published by

SPIE

P.O. Box 10, Bellingham, Washington 98227-0010 USA

Telephone +1 3606763290 (Pacific Time) · Fax +1 3606471445

SPIE.org

Copyright @ 2017 , Society of Photo-Optical Instrumentation Engineers.

Copying of material in this book for internal or personal use, or for the internal or personal use of specific clients, beyond the fair use provisions granted by the U.S. Copyright Law is authorized by SPIE subject to payment of copying fees. The Transactional Reporting Service base fee for this volume is $\$ 18.00$ per article (or portion thereof), which should be paid directly to the Copyright Clearance Center (CCC), 222 Rosewood Drive, Danvers, MA 01923. Payment may also be made electronically through CCC Online at copyright.com. Other copying for republication, resale, advertising or promotion, or any form of systematic or multiple reproduction of any material in this book is prohibited except with permission in writing from the publisher. The CCC fee code is $0277-786 \mathrm{X} / 17 / \$ 18.00$.

Printed in the United States of America.

Publication of record for individual papers is online in the SPIE Digital Library.

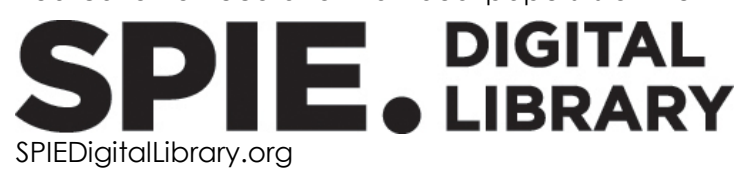

Paper Numbering: Proceedings of SPIE follow an e-First publication model. A unique citation identifier (CID) number is assigned to each article at the time of publication. Utilization of CIDs allows articles to be fully citable as soon as they are published online, and connects the same identifier to all online and print versions of the publication. SPIE uses a seven-digit CID article numbering system structured as follows:

- The first five digits correspond to the SPIE volume number.

- The last two digits indicate publication order within the volume using a Base 36 numbering system employing both numerals and letters. These two-number sets start with $00,01,02,03,04$, 05, 06, 07, 08, 09, OA, OB ... OZ, followed by 10-1Z, 20-2Z, etc. The CID Number appears on each page of the manuscript. 


\title{
Contents
}

\author{
$\checkmark$ Authors \\ vii Conference Committee
}

SESSION 1 PHENOMENOLOGY AND IMAGING

1020102 Analysis of speckle and material properties in laider tracer [10201-1]

1020104 Deep learning for SAR image formation [10201-3]

1020105 Closed-form mismatched filter synthesis for complementary range response [10201-4]

1020106 Extraction of advanced geospatial intelligence (AGI) from commercial synthetic aperture radar imagery [10201-5]

10201 OC Exploiting the sparsity of edge information in synthetic aperture radar imagery for speckle reduction [10201-11]

10201 OD Adapting range migration techniques for imaging with metasurface antennas: analysis and limitations [10201-12]

10201 OE Implications of SAR ambiguities in estimating the motion of slow targets [10201-13]

10201 OF An acceleration framework for synthetic aperture radar algorithms [10201-14]

\section{SESSION 2 FEATURE EXTRACTION AND CLASSIFICATION}

$102010 G$ A novel latent Gaussian copula framework for modeling spatial correlation in quantized SAR imagery with applications to ATR [10201-15]

$10201 \mathrm{OH}$ The efficiency of algorithms to match unique scatterer locations in joint 3D azimuth and elevation synthetic aperture radar scenarios [10201-16]

10201 OJ Using phase for radar scatterer classification [10201-18]

10201 OM Limited persistence models for SAR automatic target recognition [10201-21]

$102010 N$ Divergences and estimating tight bounds on Bayes error with applications to multivariate Gaussian copula and latent Gaussian copula [10201-22] 
Proc. of SPIE Vol. 10201 1020101-4

Downloaded From: https://www.spiedigitallibrary.org/conference-proceedings-of-spie on 26 Apr 2023 Terms of Use: https://www.spiedigitallibrary.org/terms-of-use 


\section{Authors}

Numbers in the index correspond to the last two digits of the seven-digit citation identifier (CID) article numbering system used in Proceedings of SPIE. The first five digits reflect the volume number. Base 36 numbering is employed for the last two digits and indicates the order of articles within the volume. Numbers start with 00, 01, 02, 03, 04, 05, 06, 07, 08, 09, 0A, OB...0Z, followed by 10-1Z, 20-2Z, etc.

Alexander, Winser E., OF

Bell, Thomas, 05

Benson, Jonathan W., OG, ON

Boyarsky, Michael, OD

Burns, Joseph W., OG, ON

Ertin, Emre, OM

F. Imani, Mohammadreza, OD

Frakes, David, 06

Fromenteze, Thomas, OD

Garren, David A., OE

Gloster, Clay S., OF

Goley, G. Steven, 0G, ON

Kanberoglu, Berkay, 06

Kim, Youngsoo, OF

Mason, Eric, 04

Moore, Linda J., OJ

Nolan, Adam R., OG, ON

Paulson, Christopher, $\mathrm{OC}$

Penno, Robert P., OJ

Pepin, Matthew, $\mathrm{OH}$

Pulido Mancera, Laura, OD

Reynolds, Matthew S., OD

Rigling, Brian D., 02, 0J

Ross, Jacob W., 02

Scarnati, Theresa, OC

Sleasman, Timothy, OD

Smith, David R., OD

Sugavanam, Nithin, OM

Thelen, Brian T., OG, ON

Watson, Edward A., 02

Xique, Ismael J., OG, ON

Yazici, Birsen, 04

Yonel, Bariscan, 04

Zelnio, Edmund G., 0C, OJ 
Proc. of SPIE Vol. 10201 1020101-6

Downloaded From: https://www.spiedigitallibrary.org/conference-proceedings-of-spie on 26 Apr 2023 Terms of Use: https://www.spiedigitallibrary.org/terms-of-use 


\section{Conference Committee}

Symposium Chair

Donald A. Reago Jr., U.S. Army Night Vision \& Electronic Sensors

Directorate (United States)

Symposium Co-chair

Arthur A. Morrish Raytheon Space and Airborne Systems

(United States)

Conference Chairs

Edmund Zelnio, Air Force Research Laboratory (United States)

Frederick D. Garber, Wright State University (United States)

Conference Program Committee

Joshua N. Ash, Wright State University (United States)

David Blacknell, Defence Science and Technology Laboratory (United Kingdom)

Mujdat Cetin, Sabanci University (Turkey)

Gil J. Ettinger, Systems \& Technology Research (United States)

Eric R. Keydel, Leidos, Inc. (United States)

Juan Li, University of Central Florida (United States)

Michael J. Minardi, Air Force Research Laboratory (United States)

Randolph L. Moses, The Ohio State University (United States)

Les Novak, Scientific Systems Company, Inc. (United States)

Christopher Paulson, Air Force Research Laboratory (United States)

Lee C. Potter, The Ohio State University (United States)

Brian Rigling, Wright State University (United States)

Timothy D. Ross, Jacobs Technology (United States)

David A. Garren, Naval Postgraduate School (United States)

Uttam Kumar Majumder, Air Force Research Laboratory

(United States)

Session Chairs

1 Phenomenology and Imaging

Christopher Paulson, Air Force Research Laboratory (United States)

2 Feature Extraction and Classification

Edmund G. Zelnio, Air Force Research Laboratory (United States)

Linda J. Moore, Air Force Research Laboratory (United States) 
Proc. of SPIE Vol. 10201 1020101-8

Downloaded From: https://www.spiedigitallibrary.org/conference-proceedings-of-spie on 26 Apr 2023 Terms of Use: https://www.spiedigitallibrary.org/terms-of-use 